\title{
THE ANDROGEN RECEPTOR: FUNCTIONAL STRUCTURE AND EXPRESSION IN TRANSPLANTED HUMAN PROSTATE TUMORS AND PROSTATE TUMOR CELL LINES
}

\author{
J. Trapman, ${ }^{\prime}$ C. Ris-Stalpers, ${ }^{2}$ J. A. G. M. van der Korput, ${ }^{1}$ G. G. J. M. Kuiper, ${ }^{2}$ \\ P. W. Faber, ${ }^{1}$ J. C. Romisn, ${ }^{3}$ E. MULdeR ${ }^{2}$ and A. O. BrinkmanN ${ }^{2}$ \\ Departments of 'Pathology, 'Biochemistry II and ${ }^{3}$ Urology, Erasmus University, P.O. Box 1738 , \\ 3000 DR Rotterdam, The Netherlands
}

\begin{abstract}
Summary-The growth of the majority of prostate tumors is androgen-dependent, for which the presence of a functional androgen receptor is a prerequisite. Tumor growth can be inhibited by blockade of androgen receptor action. However, this inhibition is transient. To study the role of the androgen receptor in androgen-dependent and androgen-independent prostate tumor cell growth, androgen receptor mRNA expression was monitored in six different human prostate tumor cell lines and tumors, which were grown either in vitro or by transplantation on (male) nude mice. Androgen receptor mRNA was clearly detectable in three androgen-dependent (sensitive) tumors and absent or low in three androgen-independent tumors. Growth of the $\mathrm{LNCaP}$ prostate tumor cell line can be stimulated both by androgens and by fetal calf serum. In the former situation androgen receptor mRNA expression is downregulated, whereas in the latter no effect on androgen receptor mRNA levels can be demonstrated. Sequence analysis showed that the androgen receptor gene from LNCaP cells contains a point mutation in the region encoding the steroid-binding domain, which confers an ACT codon encoding a threonine residue to GCT, encoding alanine.
\end{abstract}

\section{INTRODUCTION}

The androgen receptor is a member of the steroid/thyroid hormone/retinoic acid family of ligand-responsive transcription regulators (see for recent reviews [1-4]). The primary structure of the androgen receptor has been deduced from the sequence of the molecular cloned cDNA [5-11]. Steroid receptors are able to bind to a specific sequence (hormone responsive element) in the control region of target genes and regulate transcription of these genes.

All members of the steroid receptor family show a similar functional domain composition $[1-4]$. The $\mathrm{N}$-terminal region is variable in size and in amino acid composition and is involved in modulation of transcription activity. The transcription modulating domain is followed by the DNA-binding domain, which is highly conserved and which is structurally folded in two so-called zinc finger motifs. The C-terminal portion of the protein is essential for ligand binding and is also important for transcription activation and receptor dimerization.

Proceedings of the 2nd International EORTC Symposium on "Hormonal Manipulation of Cancer: Peptides. Growth Factors and New' (Anti-)Sieroidal Agents", Rotterdam, The Netherlands, 9-11 April 1990.
The regulation of prostate development is a complex process, which will involve an interplay of many mutually fine-tuned regulatory systems. It is well established that the androgen receptor and its cognate ligands (testosterone and dihydrotestosterone) play an essential role in this process [12]. In the developing prostate the androgen receptor seems to be mainly expressed in the mesenchymal cells. In later stages of development androgen receptor expression can also be visualized in the epithelial cells. Recent studies with specific poly- and monoclonal antibodies show that in the mature human prostate the androgen receptor is present in the secretory epithelial cells and absent in the basal cell layer. The level of androgen receptor expression in the stromal cells seems to be variable $[9,13-15]$.

The growth of the majority of prostate tumors is androgen-dependent [16]. Although initially endocrine intervention is very effective, in essentially all cases an androgen-independent tumor continues to grow. The molecular basis for the eventual failure of endocrine therapy is not known. Because of the central role of the androgen receptor in normal prostate development and in the growth of androgen-dependent tumors we investigated the expression of androgen receptor $\mathrm{mRNA}$ in human prostate tumors 
grown in vitro and in vivo. In addition, we studied the molecular structure of the androgen receptor of the $\mathrm{LNCaP}$ prostate tumor cell line [17].

\section{EXPERIMENTAL}

Growth of prostate tumors and prostate tumor cell lines

LNCaP [17] and PC-3 [18] cells were cultured in RPMI 1640 supplemented with $5 \%$ fetal calf serum (FCS) and antibiotics. PC-82, PC-EW, PC-133 and PC-135 prostate tumors were propagated as transplants on male nude mice as described [19-21], frozen in liquid nitrogen directly after removal and kept at $-70^{\circ} \mathrm{C}$ until further use.

For examination of regulation of androgen receptor mRNA expression, $\mathrm{LNCaP}$ cells were grown in medium containing steroid-depleted (dextran-charcoal treated) serum for a period of 6 days. Next, either the synthetic androgen methyltrienolone (R1881, $10^{-10} \mathrm{M}$; NEN, Boston) or FCS (5\%) was added. Incubation was continued for 6 days, cells were harvested and directly used for RNA isolation. A control culture was continuously kept in steroiddepleted medium during the same time period.

\section{Northern blot analysis}

Isolation of total cellular RNA from the different cell lines and tumors was carried out by the guanidinium thiocyanate method [22]. Northern blot analysis was performed with glyoxal denatured RNA, separated by electrophoresis on a $1 \%$ agarose gel and transferred to a nylon membrane (Genescreen, NEN, Boston). Probes $(0.5 \mathrm{~kb}$ Eco RI-Eco RI fragment, androgen receptor cDNA [7] and prostate-specific antigen cDNA clone PA 525 [23]) were labeled by standard procedures [24]. Hybridization was under stringent conditions in the presence of $50 \%$ formamide for $16 \mathrm{~h}$ at $42^{\circ} \mathrm{C}$. After washing twice with $2 \times$ SSC at $20^{\circ} \mathrm{C}$, twice with $2 \times$ SSC, $0.1 \%$ SDS for $20 \mathrm{~min}$ at $65^{\circ} \mathrm{C}$, and once with $1 \times \mathrm{SSC}$ at $20^{\circ} \mathrm{C}$, filters were dried and exposed to $\mathrm{X}$-ray film at $-70^{\circ} \mathrm{C}$ using intensifying screens.

Sequence analysis of the androgen receptor gene and $c D N A$ of $L N C a P$ cells

Total RNA and genomic DNA were isolated from $\mathrm{LNCaP}$ cells by standard procedures $[22,25]$. cDNA was prepared using $4 \mu \mathrm{g}$ of total RNA, $100 \mathrm{ng}$ of a primer complemen- tary to a fragment of the $3^{\prime}$-untranslated region of the androgen receptor mRNA and 10 units AMV reverse transcriptase (Promega, Madison, WI) in a standard protocol (Promega). Exons 2-7 and the protein coding part of exon 8 of the androgen receptor gene [26] were amplified from $1 \mu \mathrm{g}$ of genomic DNA by the polymerase chain reaction [27] using $1 \mu \mathrm{g}$ of DNA and intronspecific oligonucleotides as primers. For amplification of cDNA fragments, $2 \%$ of the first strand cDNA reaction mix and exon-specific primers were used. Amplification was performed in a Bioexcellence DNA incubator during 24 cycles. Standard conditions were: denaturation for $1 \mathrm{~min}$ at $95^{\circ} \mathrm{C}$, annealing for $2 \mathrm{~min}$ at $60^{\circ} \mathrm{C}$ and extension for $1-5 \mathrm{~min}$ at $70^{\circ} \mathrm{C}$. For sequencing, amplified fragments were made blunt ended, inserted in M13mpl8 and sequenced by the dideoxy chain termination method [28].

\section{RESULTS}

Androgen receptor $m R N A$ expression in prostate tumors/cell lines

Six different human prostate tumors/cell lines were investigated for the expression of androgen receptor mRNA by Northern blot analysis. The PC-133 and PC-135 tumors are androgenindependent and can be propagated by transplantation on nude mice [21]. The PC-82 and PC-EW tumors can be propagated on male nude mice and are androgen-dependent [19-21]. PC-3 [18] and LNCaP [17] are cell lines which can be grown in vitro; the $\mathrm{LNCaP}$ cell line is androgen-sensitive, whereas the growth of PC-3 cells is androgen-independent. Previously it has been reported that the PC-82, PC-EW and $\mathrm{LNCaP}$ cells contain high levels of androgen receptor, whereas the androgen receptor is absent or present at low concentration (PC-3) in the other cell lines/tumors [17, 29,21 and refs herein]. The results of the Northern blot experiments are summarized in Table 1. The expression of the androgen receptor mRNA

Table 1. Androgen receptor mRNA expression in human prostate tumor cell lines and transplanted tumors

\begin{tabular}{lccc}
\hline & $\begin{array}{c}\text { Androgen } \\
\text { dependent } \\
\text { (sensitive) }\end{array}$ & $\begin{array}{c}\text { AR } \\
\text { mRNA }\end{array}$ & $\begin{array}{c}\text { AR } \\
\text { protein } \\
\text { (refs }[17,21,29])\end{array}$ \\
\hline PC-3 & - & - & $+i-$ \\
PC-82 & + & ++ & ++ \\
PC-EW & + & ++ & ++ \\
PC-133 & - & - & - \\
PC-135 & - & - & +++ \\
LNCaP & + & +++ & ++ \\
\hline
\end{tabular}


correlates precisely with androgen receptor protein levels. Obviously, in the androgenresponsive cells androgen receptor mRNA can be detected. In contrast, in the androgen-independent cells, not only the androgen receptor is absent, but also the corresponding mRNA.

Regulation of androgen receptor $m R N A$ expression in LNCaP cells

To study further regulation of androgen receptor mRNA expression in prostate cells, LNCaP cells were cultured in steroid-depleted medium and subsequently their growth was stimulated by the addition of fetal calf serum up to a concentration of $5 \%$ or the synthetic androgen R1881 $\left(10^{-10} \mathrm{M}\right)$ (Fig. 1A and Refs [17, 30]). RNA was extracted from serum- and R1881treated cells and androgen receptor mRNA expression was compared with the control culture in steroid-depleted medium. In addition, regulation of androgen receptor mRNA expression was compared with that of mRNA of the prostate-specific tumor marker prostatespecific antigen [23]. As can be seen, both R1881 and fetal calf serum strongly increased the level of prostate-specific antigen mRNA (Fig. 1C). In contrast, androgen receptor mRNA expression was downregulated by R1881 treatment and stable or slightly upregulated by serum treatment (Fig. 1B). Because both addition of fetal calf serum and R1881 to the culture resulted in growth stimulation of LNCaP cells, these data point to a complex mechanism of androgen receptor mRNA expression in correlation with cell growth.

Structure of the androgen receptor for LNCaP cells

Previously we reported the aberrant affinity for steroid hormones of androgen receptor preparations from LNCaP cells [31, 32]. In order to establish whether a mutation in the androgen receptor gene could be the cause of its abnormal properties, androgen receptor cDNA, and the exons $2-7$ and the protein coding part of exon 8 of the androgen receptor gene were sequenced after amplification of the appropriate fragments by the polymerase chain reaction. In the androgen receptor gene as well as the cDNA one point mutation was detected. This mutation (A to $\mathrm{G}$ ) resulted into the transition of aminoacid residue 868 , threonine into an alanine (Fig. 2). It is tempting to speculate that this mutation is the cause of the modified specificity of the receptor.
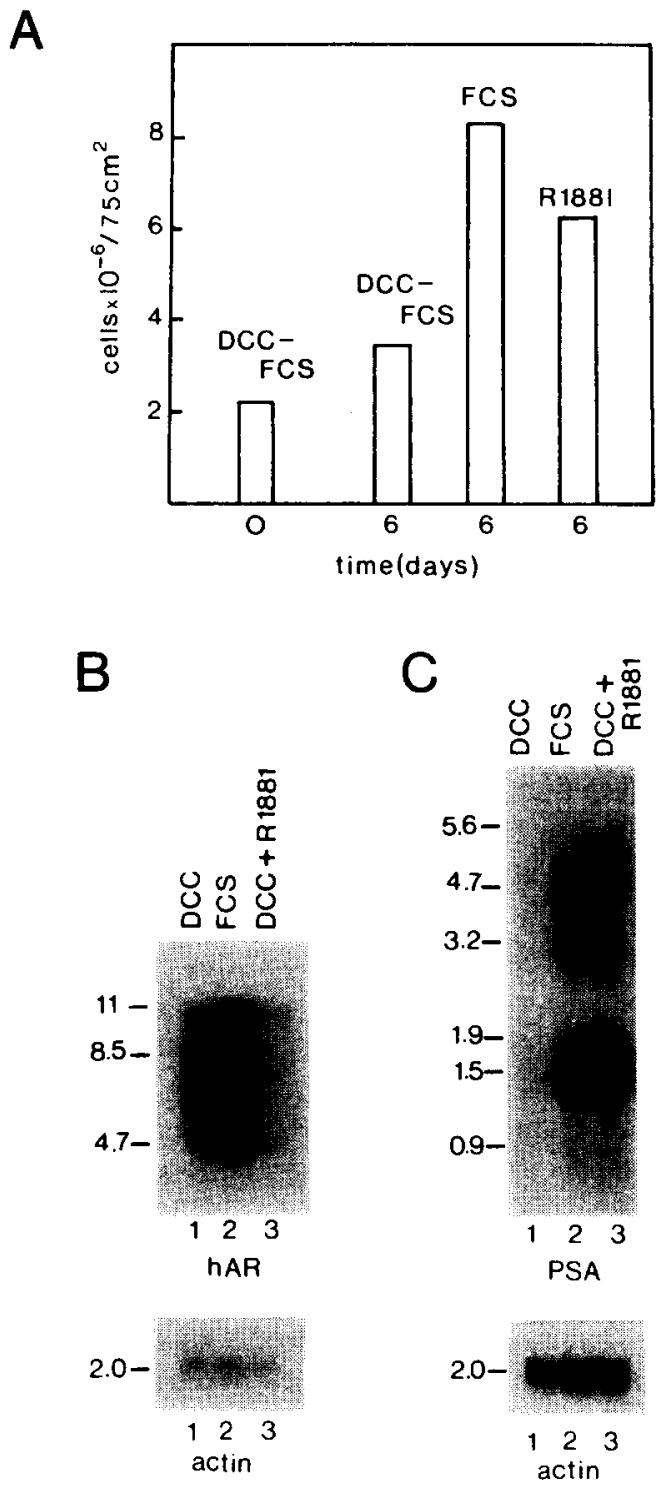

Fig. 1. Growth regulation of the human prostate carcinoma cell line LNCaP (A), regulation of androgen receptor mRNA expression (B) and regulation of prostate-specific antigen mRNA expression (C) by R1881 and fetal calf serum. Experimental details are described in the Experimental section. Abbreviations: DCC or DCC-FCS: Dextrancharcoal-treated fetal calf serum; hAR: human androgen receptor; PSA: prostate-specific antigen. For sizes of mRNA species (in kb) see refs [7] and [23]. Hybridization of the Northern blots with an actin probe was used as an internal control.

\section{DISCUSSION}

The molecular mechanisms of prostate tumor cell growth are not understood. A key molecule in normal prostate development and in androgen-dependent prostate tumor growth is the androgen receptor. In this study the regulation of expression of androgen receptor mRNA and the structure of the androgen receptor of LNCaP cells are described. 


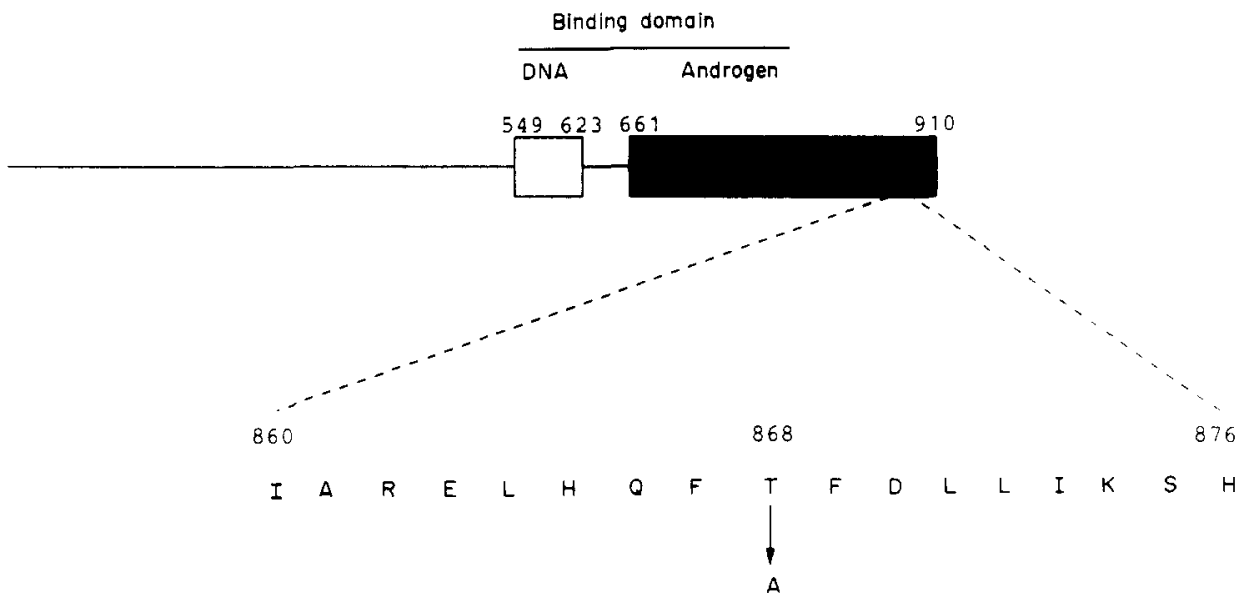

Fig. 2. Schematical representation of the androgen receptor structure. The open box (amino-acids 549-623) shows the DNA-binding domain; the closed box (amino-acids 661-910) the steroid-binding domain. The mutation in the androgen receptor of $\mathrm{LNCaP}$ cells (threonine to alanine) is at position 868 .

First of all, it was observed that androgen receptor mRNA is absent or present in only very low concentrations in androgen-independent human prostate cell lines and transplanted human prostate tumors, showing that downregulation of androgen receptor expression in androgen-independent cell lines/tumors is on the mRNA level (Table 1). The downregulation of androgen receptor mRNA expression can be caused by an increased degradation rate of the mRNA, but more likely by a decrease in transcription rate of the androgen receptor gene.

Similar findings were recently reported in the rat Dunning prostate tumor model [33]. In most, but not all, androgen-independent sublines of the Dunning prostate tumor, androgen receptor mRNA expression was downregulated, whereas it was present in the androgendependent cell lines. Interestingly, androgen receptor mRNA could clearly be detected in the androgen-independent sublines, which were derived directly from the original androgendependent tumor. This indicates that loss of androgen receptor mRNA expression can be a functional late step in progressive tumor growth. Alternatively, the absence of androgen receptor mRNA in androgen-independent cell lines/tumors might simply be due to loss of differentiated functions of the tumor cells during long-term in vitro culture or transplantation, which is not a reflection of the situation in vivo. Recent immunohistochemical analysis of tissue sections of human prostatectomy specimens showed that the androgen receptor is present in essentially all differentiated tumor growth patterns, whereas androgen receptor expression seems more variable in undifferenti- ated tumor growth patterns [14]. Extension of these experiments and detailed investigation of androgen receptor expression during tumor growth will have to be carried out in order to determine whether the presence or absence of a (functionally active) androgen receptor plays a role in human prostate cancer progression.

Analysis of regulation of androgen receptor mRNA expression in the androgen-sensitive $\mathrm{LNCaP}$ cell line showed that there is no strict correlation between cell growth and androgen receptor mRNA level. Stimulation of LNCaP growth by the synthetic androgen R1881 is accompanied by downregulation of androgen receptor mRNA levels. If full serum is used for growth stimulation such a downregulation cannot be observed. The latter indicates that components other than testosterone, which have been removed from the serum by dextrancharcoal treatment can contribute to regulation of androgen receptor mRNA levels. Whether this is on the level of gene transcription remains to be established.

The mutation detected at position 868 in the steroid-binding domain of the androgen receptor of LNCaP cells is of high interest. This mutation might render the androgen receptor more susceptible to activation by steroids other than testosterone and dihydrotesterone (e.g. progesterone, oestradiol) [31, 32]. The mutated receptor seems to be completely functional. Not only cell growth can be stimulated by R 1881 , but also prostate-specific antigen mRNA expression can be upregulated (Fig. 1). It is tempting to speculate that the mutation plays a role in progressive prostate tumor growth. In this respect it is of importance that the tumor from 
which the LNCaP cell line is derived continued to grow during estrogen therapy [34].

Acknowledgements-We thank Mrs Paula Delfos for photography. This study was supported by grants from the Dutch Cancer Society (KWF) and NWO-Medigon.

\section{REFERENCES}

1. Green S. and Chambon P.: Nuclear receptors enhance our understanding of transcription regulation. Trends Genet. 4 (1988) 309-314.

2. Evans R. M.: The steroid and thyroid hormone receptor superfamily. Science 240 (1988) 889-895.

3. Beato M.: Gene regulation by steroid hormones. Cell $\mathbf{5 6}$ (1989) 335-344

4. Carson-Jurica M. A., Schrader W. T. and O'Malley B. W.: Steroid receptor family: structure and functions. Endocr. Rev. 11 (1990) 201-220.

5. Chang C., Kokontis J. and Liao S.: Molecular cloning of human and rat complementary DNA encoding androgen receptors. Science 240 (1988) 324-326.

6. Lubahn D. B., Joseph D. R., Sullivan P. M., Willard H. F., French F. S. and Wilson E. M.: Cloning of human androgen receptor complementary DNA and localization on the X chromosome. Science 240 (1988) 327-330.

7. Trapman J., Klaassen P., Kuiper G. G. J. M., van der Korput J. A. G. M., Faber P. W., van Rooij H. C. J., Geurts van Kessel A., Voorhorst M. M., Mulder E. and Brinkmann A. O.: Cloning, structure and expression of a cDNA encoding the human androgen receptor. Biochem. Biophys. Res. Commun. 153 (1988) 241-248.

8. Chang C., Kokontis J. and Liao S.: Structural analysis of complementary DNA and amino acid sequences of human and rat androgen receptors. Proc. Natl. Acad. Sci. U.S.A. 85 (1988) 7211-7215.

9. Lubahn D. B., Joseph D. R., Sar M., Tan J-A., Higgs H. N., Larson R. E., French F. S. and Wilson E. M.: The human androgen receptor: complementary deoxyribonucleotide cloning, sequence analysis and gene expression in prostate. Mol. Endocrinol. 2 (1988) $1265-1275$.

10. Faber P. W., Kuiper G. G. J. M., van Rooij H. C. J., van der Korput J. A. G. M., Brinkmann A. O. and Trapman J.: The N-terminal domain of the human androgen receptor gene is encoded by one large exon. Mol. Cell. Endocrinol. 61 (1989) 257-262.

11. Tilley W. D., Marcelli M., Wilson J. D. and McPhaul M. J.: Characterization and expression of cDNA encoding the human androgen receptor. Proc. Natl. Acad. Sci. U.S.A. 86 (1989) 327-331.

12. Cunha G. R., Donjacour A. A., Cooke P. S., Mee S., Bigsby R. M., Higgins S. J. and Sugimur Y.: The endocrinology and developmental biology of the prostate. Endocr. Rev. 8 (1987) 338-362.

13. Van Laar J. H., Voorhorst-Ogink M. M., Zegers N., Boersma W., Van der Korput J. A. G. M., Ruizeveld de Winter J. A., Van der Kwast Th. H., Mulder E., Trapman J. and Brinkmann A. O.: Characterization of antibodies against the $\mathrm{N}$-terminal domain of the human androgen receptor. Mol. Cell. Endocrinol. 67 (1989) 29-38.

14. Ruizeveld de Winter J. A., Trapman J., Brinkmann A. O., Boersma W. J. A., Mulder E., Schroeder F. H., Claassen E. and Van der Kwast Th. H.: Androgen receptor heterogeneity in human prostatic carcinomas visualized by immunohistochemistry. J. Pathol. 161 (1990) 329-332.

15. Husmann D. A., Wilson C. M., McPhaul M. J., Tilley C. M. and Wilson J. D.: Antipeptide antibodies to two distinct regions of the androgen receptor localize the receptor protein to the nuclei of target cells in the rat and human prostate. Endocrinol. 126 (1990) 2359-2368.

16. Coffey D. S. and Pienta K. J.: New concepts in studying the control of normal cancer growth of the prostate. Prog. Clin. Biol. Res. 239 (1987) 1-73.

17. Horoszewicz J. S., Leong S. S., Kawinski E., Karr J., Rosenthal H., Chu T. M., Mirand E. A. and Murphy G. P.: LNCaP model of human prostatic carcinoma. Cancer Res. 43 (1983) 1809-1818.

18. Kaighn M. E., Narayan K. S., Ohnuki Y., Lechner J. F. and Jones L. W.: Establishment of a human prostatic carcinoma cell line (PC-3). Invest. Urol. 17 (1979) 16-23.

19. Hoehn W., Schroeder F. H., Riemann J. F., Joebsis A. C. and Hermanek P.: Human prostatic adenocarcinoma: some characteristics of a serially transplantable line in nude mice (PC-82). The Prostate 1 (1980) 95-104.

20. Hoehn W., Wagner M., Riemann J. F., Hermanek P., Williams E., Walther R. and Schrueffer R.: Prostatic adenocarcinoma PC-EW, a new human tumor line transplantable in nude mice. The Prostate 5 (1984) 445-452

21. Van Steenbrugge G. J.: Transplantable human prostate cancer (PC-82) in athymic nude mice: a model for the study of androgen-regulated tumor growth. Ph.D. Thesis, Rotterdam (1988).

22. Chirgwin J. M., Przybyla A. E., MacDonald R. J. and Rutter W. J.: Isolation of biologically active ribonucleic acid from sources enriched in ribonuclease. Biochemistry 18 (1977) 5294-5299.

23. Riegman P. H. J., Klaassen P., Van der Korput J. A. G. M., Romijn J. C. and Trapman J.: Molecular cloning and characterization of novel prostate antigen cDNAs. Biochem. Biophys. Res. Commun. 155 (1988) 181-188.

24. Feinberg A. P. and Vogelstein P.: A technique for radiolabeling DNA restriction endonuclease fragments to high specific activity. Anal. Biochem. 132 (1983) 6-13.

25. Maniatis T., Fritsch E. F. and Sambrook J.: Molecular Cloning: A Laboratory Manual. Cold Spring Harbor Laboratory, Cold Spring Harbor, NY (1982).

26. Kuiper G. G. J. M., Faber P. W., van Rooij H. C. J., van der Korput J. A. G. M., Ris-Stalpers C., Klaassen P., Trapman J. and Brinkmann A. O.: Structural organization of the human androgen receptor gene. J. $\mathrm{Mol}$. Endocrinol. 2 (1989) R1-R4.

27. Siaki R. K., Gelfand D. H., Stoffel S., Scharf S. J., Higuchi R., Horn G. T., Mullis K. B. and Ehrlich H. A.: Primer-directed enzymatic amplification with a thermostable DNA polymerase. Science 239 (1988) 487-491.

28. Sanger F., Nicklen S. and Coulson A. R.: DNA sequencing with chain-terminating inhibitors. Proc. Natl. Acad. Sci. U.S.A. 74 (1977) 5463-5467.

29. Brinkmann A. O., Bolt J., Van Steenbrugge G. J., Kuiper G. G. J. M., De Boer W. and Mulder E.: Characterization of androgen receptors in a transplantable human prostatic adenocarcinoma (PC-82). The Prostate 10 (1987) 133-143.

30. Berns E. M. J. J., De Boer W. and Mulder E.: Androgen dependent growth regulation of and release of specific protein(s) by the androgen receptor containing human prostate tumor cell line LNCaP. The Prostate 9 (1986) $247-259$.

31. Schuurmans A. L. G., Bolt J., Voorhorst M. M., Blankenstein M. A. and Mulder E.: Regulation of growth and epidermal growth factor receptor levels of LNCaP prostate tumor cells by different steroids. Int. $J$. Cancer 42 (1988) 917-922.

32. Veldscholte J., Voorhorst-Ogink M. M., Bolt-de Vries J., Van Rooij H. C. J., Trapman J. and Mulder E. Unusual specificity of the androgen receptor in the human prostate tumor cell line LNCaP: high affinity for progestagenic and estrogenic steroids. Biochim. Biophys. Acta 1052 (1990) 187-194. 
33. Quarmby V. E., Beckman W. C., Cooke D. B., Lubahn D. B., Joseph D. R., Wilson E. M. and French F. S.: Expression and localization of androgen receptor in the R-3327 Dunning rat prostatic adenocarcinoma. Cancer Res. 50 (1990) 735-739.
34. Horoszewicz J. S., Leong S. S., Ming Chu T., Wajsman Z. L., Friedman M., Papsidero L., Kim U., Chai L. S., Kakati S., Arya S. K. and Sandberg A. A.: The LNCaP cell line-a new model for studies on human prostatic carcinoma. Prog. Clin. Biol. Res. 37 (1980) 115-132. 